\title{
AOR
}

Selected Papers of \#AolR2018: The $19^{\text {th }}$ Annual Conference of the Association of Internet Researchers Montréal, Canada / 10-13 October 2018

\section{LEGITIMATING INTERNET.ORG THROUGH DEVELOPMENT DISCOURSE}

Andrea Alarcon

University of Southern California

This is an amazing story about Riza -- a young woman on a small island where the only job for women was collecting seashells, yet she used Internet.org to earn a degree in computer science. Being connected means having opportunity. We're going to connect the whole world so one day everyone can achieve their full human potential -- just like Riza. (Mark Zuckerberg, 2015)

This was Zuckerberg's personal post about one of the promotional videos for Facebook's Internet.org initiative, launched in 2013, currently available to 100 million people. Internet.org is a partnership between Facebook and telecommunication companies that plans to bring affordable access to selected Internet services to less developed countries, partly through data subsidies. During this time, Zuckerberg released a ten-page white paper elaborating on the vision that asserts that connectivity is a "human right". The vision is an example of what Jasanoff and Kim (2015) called "sociotechnical imaginaries", which, they argue, are not limited to nations, or heads of states, but can be conjured by corporations, social movements, and professional societies. Digital rights advocates, critics, popular media and scholars (Samarajiva 2012; Galpaya, 2017) criticized the project on the grounds of violation of network neutrality, and for handpicking the internet services provided, calling it "a second-tier internet for the poor". Due to these objections India pushed the initiative out of the country in 2015. Some of these issues have been addressed since then. Yet the name in itself highlights the importance of discourse, since "Internet.org" implies both that it is actually the internet, and that it is a non-for-profit initiative. It forms part of a larger initiative by various technology companies in conjunction with aid agencies and the UN called "Alliance for affordable Internet". Through a critical discourse analysis of promotional videos, this paper argues that by discursively merging Internet.org with connectivity, and connectivity as the key to addressing other development issues (like rural education for Riza) Facebook uses development discourse as a tool for legitimation of Internet.org. David Nye calls "micro-narratives", stories that are not a Suggested Citation (APA):, Alacon, A, Legitimating Internet.Org Through Development Discourse. (2018, October 10-13) Paper presented at AolR 2018: The $19^{\text {th }}$ Annual Conference of the Association of Internet Researchers. Montréal, Canada: AolR. Retrieved from http://spir.aoir.org. 
"full-scale narrative of utopia" but are "presented as stories about a better world". Examples of the micro-narratives in these videos include education, such as computer science for Riza, Karmel in Bangladesh who teaches children how to swim, entrepreneurship, such as Marissa, trying to start her own clothing line, and Paula in Colombia, utilizing it for agricultural advice from an online community.

Zuckerberg narrates his own story in one of the promotional videos for Internet.org, making the link to the larger imaginary: "I could build [Facebook] because I had access to the internet and a few basic tools... If...everyone around the world has access to the same tools, then everyone is going to be able to benefit from the hard work and ideas around the world" (Facebook, 2013). The link from him to the other highlighted stories, goes hand in hand with modernization and development narratives: progress is available to whoever wishes to take it. The smaller narratives, as opposed to Zuckerberg's larger claims about a connected world, ground the dream, since they finish by saying "this is happening now." It intersects with development discourse by positioning itself as the one-way line to progress that has been associated with modernity and economic development.

Many scholars have spoken about the hopes, dreams and expectations attached to technology (Jasanoff \& Kim, 2015; Kling 1996; Nye 1997, 2008; Sturken et al 2004; Turner 2010;). Yet this paper aims to add to critical ICTD scholarship (Information, Communication, Technologies for Development), which mainly utilizes what Amartya Sen called "development as freedom" as framework, arguing for greater agency to users. They argue for broadening the study of technology users in developing countries, in a way that understands them as more than "simple-minded utilitarian beings" (Arora \& Baransky 2013), which is typical of development discourse and projects. Therefore several scholars in ICTD studies (Arora, 2010, 2012; Burrell 2016; Kleine, 2011; Ganesh, 2010; Mitra, 2005; Kavoori and Arceneaux, 2006; Rangaswamy \& Sambasivan 2011) have asked for more holistic approaches to studying technology use by people in the "global south", including leisure and non-utilitarian uses, and position them within larger contexts. The program began by showing fully utilitarian uses such as the ones described above, yet slowly (but scarcely) moved into a few less utilitarian ones, such as checking soccer scores and gym routines.

Reality, scholar Arturo Escobar claims, has been "colonized by the development discourse" (2011, p.5) It dominates the way in which Africa, Asia, and Latin America are represented at the global level. The development narratives are based on "imperfections or deficiencies (of capital, of technology, of knowledge... to make projects happen" (Escobar, 2011, p.163). With the videos, Facebook highlights the imperfections and deficiencies, of technology mostly, to make this particular project happen.

Riza's video, for example, a first-person narration states the following:

I live on a small island. The only job for women here is gathering seashells. But I wanted something greater for myself. So I decided to study computer science in town. I traveled by boat every day just to go to school. When I was writing my thesis there was a strong typhoon. I could not leave the island for weeks. My phone became a classroom to communicate with my group mates. We used 
Facebook through Internet.org to write our thesis... Automated Water Billing System of Culasi Water District. (Facebook, October 2, 2015 : Riza)

The video includes a shot of her on a tiny boat wearing her cap and gown, standing fierce in a rough ocean. The video's imagery contrasts the deficiencies: remoteness, poverty, gender, with empowerment that can come from technology, perfectly fusing poverty alleviation with the techno-solution that is Internet.org. The development agenda of gender empowerment and equality has been leading development discourse for more than a decade (Wilkins, 2016), particularly in relationship to education. Her phone "became a classroom". We find out she is in Antigua thanks to third party sources, not the video, but also, in his Facebook post, Zuckerberg does not explain that she was getting her degree in an IT center, and Internet.org was for homework coordination, further collapsing the program with the internet. "The rural development discourse repeats the same relations that has defined development discourse since its emergence: the fact that development is about growth, about capital, about technology, about becoming modern. Nothing else" (Escobar, 2011, p.162). The videos encompass the traditional development themes, images, and buzzwords such as maternal health, rural education, entrepreneurship, female empowerment, transnational collaboration, and in later years "partnerships" with local organizations. Raymond Williams states that particular combinations of words 'establish one set of connections while often suppressing another' (1976: 25). If, as Escobar says, "reality is colonized by the development discourse" we can see how Zuckerberg is merging the grander narratives of Silicon Valley and development, and latching on to the already legitimized and accepted understandings of what constitutes for "good", "aid" and "progress".

\section{References}

Arora, P., \& Rangaswamy, N. (2013). Digital leisure for development: Reframing new media practice in the Global South. Media, Culture \& Society, 35(7), 898-905. Burrell, J. (2016). Material ecosystems: Theorizing (digital) technologies in socioeconomic development. Information Technologies \& International Development, 12(1), pp-1.

Escobar, A. (2011). Encountering Development: The Making and Unmaking of the Third World. Princeton University Press.

Facebook. [Internet.org by Facebook ]. (2015, October 2 ). Riza

[Video file]. Retrieved from

https://www.facebook.com/Internetdotorg/videos/911610822268307/

Facebook. [Internet.org by Facebook ]. (2013, August 30). Announcing Internet.org [Video file]. Retrieved from https://www.facebook.com/Internetdotorg/videos/484896038273123/

Galpaya, H. (2017). Zero-rating in emerging economies.

Ganesh IM (2010) Mobile Love Videos Make Me Feel Healthy: Rethinking ICTs for Development. IDS Working Paper 352. Brighton: IDS. 
Mitra S (2005) Self-organising systems for mass computer literacy: findings from the 'hole in the

Wall' experiments. International Journal of Development Issues 4(1): 71-81.

Jasanoff, S., \& Kim, S.-H. (2015). Dreamscapes of Modernity:

Sociotechnical Imaginaries and the Fabrication of Power. University of Chicago Press.

Kavoori A and Arceneaux N (eds) (2006) The Cell Phone Reader: Essays in Social Transformation.New York: Peter Lang.

Kling, R. (1996). Hopes and Horrors: Technological Utopianism and Anti-Utopianism in Narratives of. Computerization and controversy: Value conflicts and social choices, 40.

Nye, D. E. (1997). Narratives and Spaces: Technology and the construction of American culture. Columbia University Press.

Nye, D. (2004) Technological prediction, a promethean problem. In Sturken, M., Thomas, D., \& Ball-Rokeach, S. Technological Visions: The Hopes and Fears that Shape New Technologies. Temple University Press.

Rangaswamy N and Sambasivan N (2011) Cutting chai, Jugaad, and Here Pheri: Towards a UbiComp for a Global community. Personal and Ubiquitous Computing 15(6): 553-564.

Samarajiva, R. (2012) Facebook = Internet? LIRNEAsia. Retrieved from: http://lirneasia.net/2012/05/facebook-internet/

Sturken, M., Thomas, D., \& Ball-Rokeach, S. (Eds.). (2004). Technological visions: The hopes and fears that shape new technologies. Temple University Press.

Turner, F. (2010). From counterculture to cyberculture: Stewart Brand, the Whole Earth Network, and the rise of digital utopianism. University of Chicago Press.

The Economist. (n.d.). EIU Inclusive Internet Index. Retrieved from https://theinclusiveinternet.eiu.com/explore/countries/performance

Wilkins, K. (2016). Communicating gender and advocating accountability in global development. Springer. 